\title{
Arene Ruthenium(II) Complexes with Phosphorous Ligands as Possible Anticancer Agents
}

\author{
Lorenzo Biancalana, Guido Pampaloni, and Fabio Marchetti ${ }^{\star}$
}

\begin{abstract}
Ruthenium(II) complexes of formula $\left[\mathrm{Ru}\left(\eta^{6}\right.\right.$-arene) $\left.\mathrm{Cl}_{2}(\mathrm{PTA})\right]$ (RAPTA) are potential anticancer drugs with notable antimetastatic and antiangiogenic activity, which are now pointing to clinical trials. Following the great interest aroused by these compounds, a variety of RAPTA derivatives, obtained by chloride substitution and/or containing functionalized arene ligands, and complexes resembling the RAPTA structure but bearing different phosphorous ligands have been synthesized and evaluated for their anticancer activity. An overview of all of these biologically relevant complexes will be given, with particular reference to the anticancer behaviour exhibited by the compounds and the possible relationship with structural aspects.
\end{abstract}

Keywords: Anticancer Drugs · Bioactive groups · Phosphorus ligand · RAPTA · Ruthenium arene compounds

\section{Ruthenium Compounds as Possible Anticancer Drugs}

The search for new and effective anticancer drugs that overcome the limitations of platinum-based chemotherapy currently used in clinical treatments still represents one of the most important objectives of modern science. ${ }^{[1]}$ In this respect, ruthenium compounds play a major role, since it is generally accepted that ruthenium is relatively less toxic than platinum and other heavy metals, and two ruthenium compounds, i.e. KP1019 and NAMI-A, reached phase II of clinical trials (Fig. 1).[2] It is believed that these $\mathrm{Ru}(\mathrm{III})$ species act as pro-drugs, in that they are converted into the active $\mathrm{Ru}$ (II) form by one electron reduction in the tumour environment. [3] This hypothesis has triggered the investigation directly on a variety of $\mathrm{Ru}(\mathrm{II})$ compounds, and those based on the Ru-arene scaffold have aroused major attention. ${ }^{4]}$ In particular, $\left[\mathrm{Ru}\left(\eta^{6}\right.\right.$-arene) $\mathrm{Cl}_{2}(\kappa P$-PTA)] (RAPTA complexes), containing the peculiar phosphine ligand 1,3,5-triaza-7-phosphatricyclo[3.3.1.1]decane called PTA, ${ }^{[5]}$ and $\left[\mathrm{Ru}\left(\eta^{6}\right.\right.$-biphenyl $)$ $\left.\mathrm{Cl}\left(\kappa^{2} \mathrm{~N}-\mathrm{NH}_{2} \mathrm{CH}_{2} \mathrm{CH}_{2} \mathrm{NH}_{2}\right)\right] \mathrm{X}\left(\mathrm{X}=\mathrm{PF}_{6}, \mathrm{Cl}\right.$, RM-175), ${ }^{[6]}$ containing a bidentate ethylene-1,2-diamine ligand, have emerged as

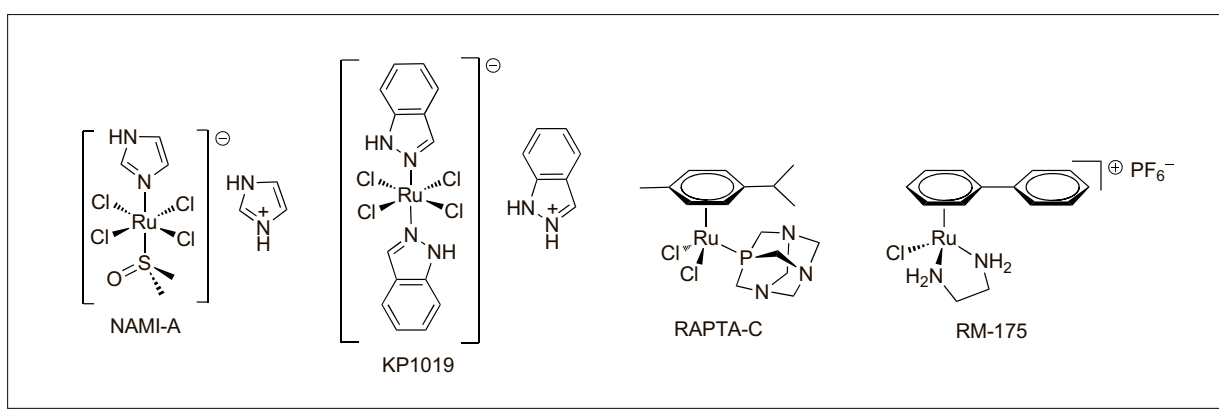

Fig. 1. Most prominent ruthenium compounds investigated as possible anticancer drugs.

among the most promising therapeutics, showing great anticancer properties in vivo (Fig. 1). ${ }^{[7]}$ Following these successful discoveries, many other derivatives have been explored for their anticancer potential; in this review, we will give a state of the art of ruthenium arene compounds containing phosphorous ligands that have been investigated.

\section{Ruthenium Complexes with a PTA Ligand}

A vast series of compounds of general formula $\left[\mathrm{Ru}\left(\eta^{6}\right.\right.$-arene $) \mathrm{Cl}_{2}(\kappa P$-phosphine $\left.)\right]$ can be easily obtained by addition of a monodentate phosphine to the correspond- ing precursor $\left[\mathrm{Ru}\left(\eta^{6} \text {-arene }\right) \mathrm{Cl}_{2}\right]_{2}$, via symmetric cleavage of the dinuclear frame (Scheme 1). ${ }^{[8]}$

The resulting complexes are usually air stable, even when containing air-sensitive phosphines in normal conditions. This procedure works well with 1,3,5-triaza-7-phosphatricyclo[3.3.1.1]decane (PTA) too, affording RAPTA complexes developed by Dyson and co-workers, ${ }^{[9]}$ that are generally non cytotoxic. However, investigations on their antitumor efficacy have been carried out on animal models: in particular, $\left[\mathrm{Ru}\left(\eta^{6}-p\right.\right.$-cymene $) \mathrm{Cl}_{2}(\kappa P$ PTA)], RAPTA-C (Fig. 1), was shown to be effective in reducing the growth of lung metastases in mice affected by mammary carcinoma in the absence of a correspond-

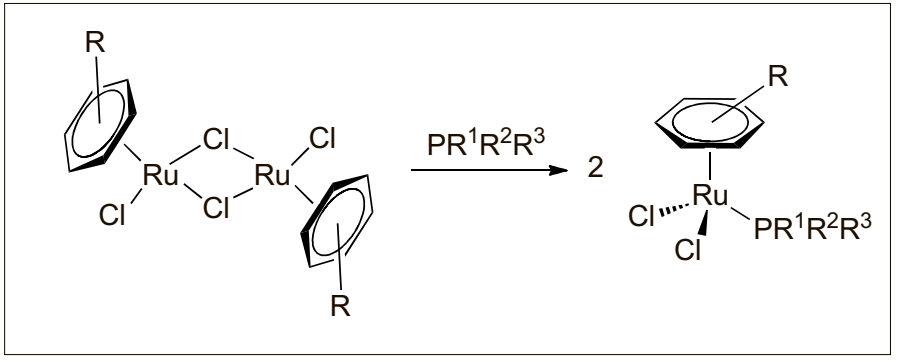

Scheme 1. General synthesis of $\mathrm{Ru}(\mathrm{II})$ arene phosphine complexes. 
ing action against the primary tumour. Moreover, RAPTA-C is able to reduce the growth of ovarian and colorectal carcinomas, and a relatively low dose per day $\left(0.2 \mathrm{mg} \mathrm{kg}^{-1}\right)$ is optimal against the A2780 ovarian carcinoma. ${ }^{[10]}$ According to biodistribution studies, ruthenium is rapidly released from the organs and the bloodstream through excretion by the kidneys, that is a desirable feature in view of possible clinical applications. ${ }^{[11]}$

A multi-targeted mechanism of action has been proposed for RAPTA compounds, with preferential binding to chromatin and cancer-related proteins that may be responsible for the observed antiangiogenic and antimetastatic activities. ${ }^{[12]}$ The mode of action appears to be related to the hydrolysis of one $\mathrm{Ru}-\mathrm{Cl}$ bond, this hydrolysis being suppressed at high chloride concentrations. ${ }^{[13]}$

A range of ruthenium arene-PTA compounds have been prepared as variants of the RAPTA, in order to evaluate the anticancer potential. Even RAPTA analogues based on $\mathrm{Rh}$ and Os have been synthe-
Scheme 2. RAPTA-type compounds: a) arene linked diruthenium complexes; b) arene functionalization with hydrogen bonding functionalities; c) arene functionalization with fluorinated groups.

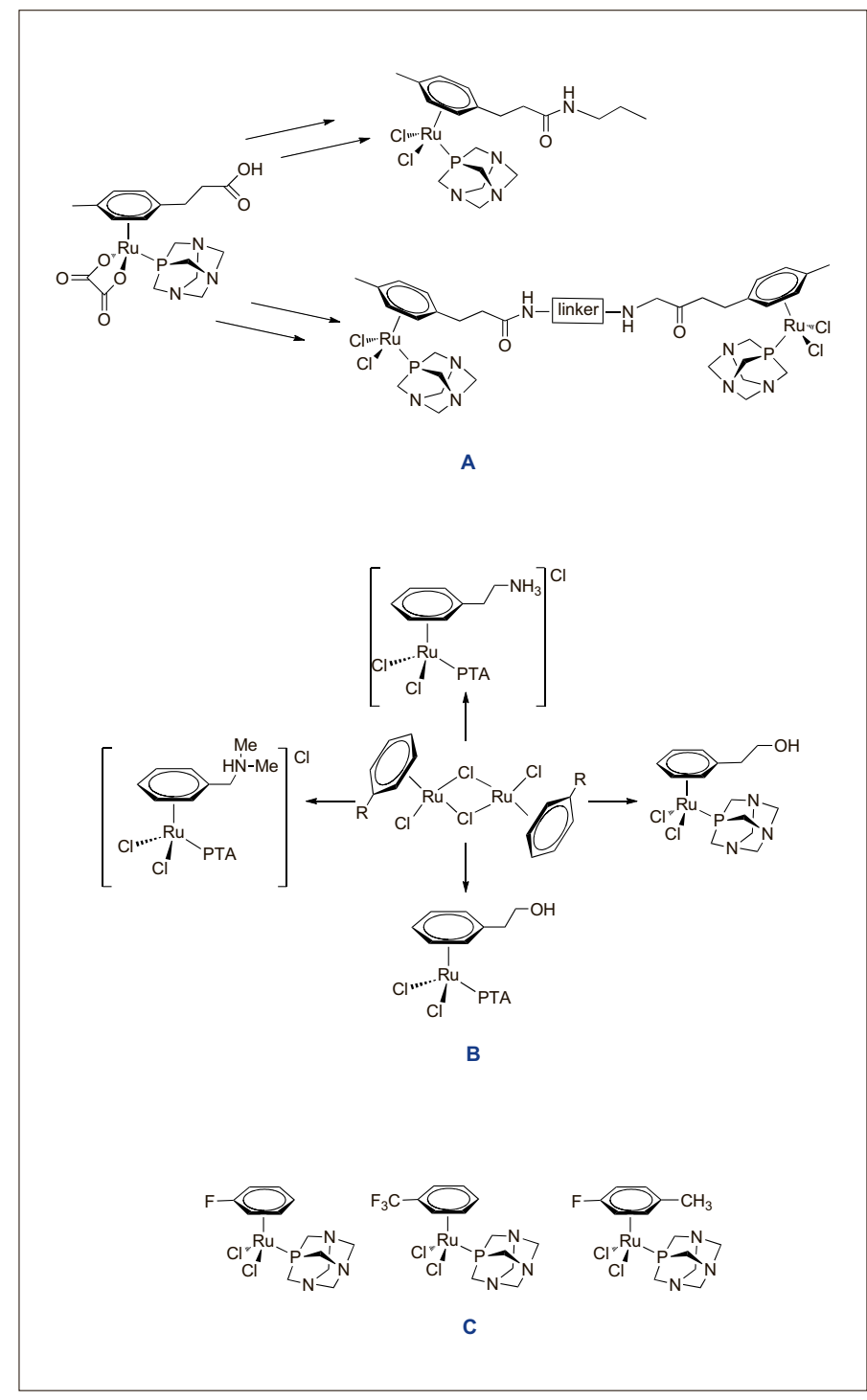

Scheme 3. Synthesis of chloroambucilfunctionalized arene RAPTA complex.

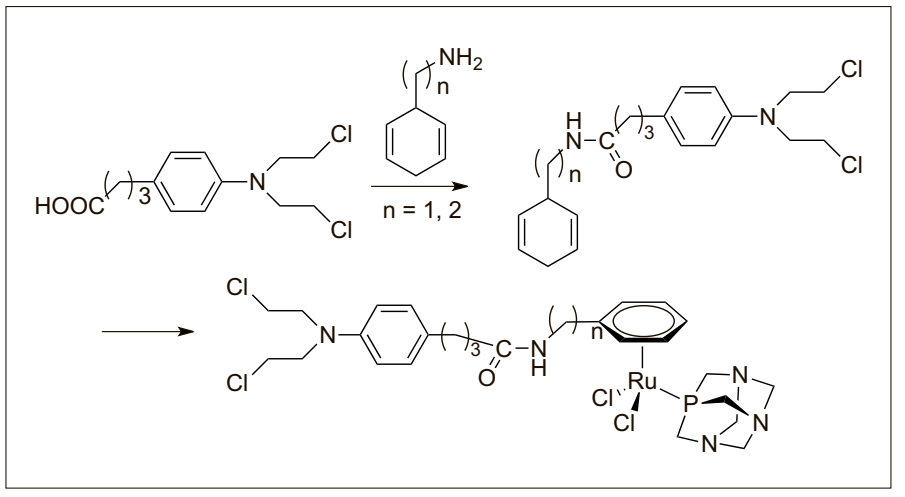

sized, and subsequent in vitro experiments showed promising results on HT29 colon carcinoma, A549 lung carcinoma, and T47D breast carcinoma cells. ${ }^{[14]}$

Complexes $\quad\left[\mathrm{Ru}\left(\eta^{6}-p\right.\right.$-cymene $)\left(\kappa^{2} O\right.$ $\left.\left.\mathrm{C}_{2} \mathrm{O}_{4}\right)(\mathrm{PTA})\right]$ and $\left[\mathrm{Ru}\left(\eta^{6}-p\right.\right.$-cymene $)$ $\left.\left(\mathrm{K}^{2} \mathrm{O}-\mathrm{C}_{6} \mathrm{H}_{6} \mathrm{O}_{4}\right)(\mathrm{PTA})\right]$ (Fig. 2), containing a bis-carboxylate ligand, are considerably more soluble and more inert than their respective RAPTA precursors. These compounds, studied for their antiproliferative activity against HT29 colon carcinoma, A549 lung carcinoma, and T47D and MCF7 breast carcinoma cell lines, were found to exhibit a similar activity compared to that of RAPTA-C, suggesting their potential as possible antimetastatic agents. ${ }^{[15]}$

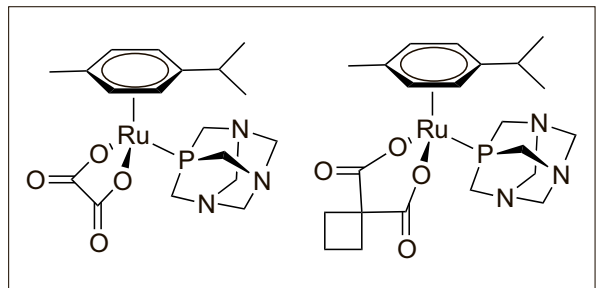

Fig. 2. RAPTA-C derivatives with a biscarboxylate ligand.

Modification of the arene moiety was also attempted in order to modulate the biological behaviour of RAPTA compounds. Hence, arene-linked diruthenium RAPTA complexes were revealed to be significantly more cytotoxic than the classical RAPTA series (Scheme 2a). ${ }^{[16]}$

The introduction in the arene ring of potential hydrogen bonding functionalities was inspired by the fact that similar substitution in titanocene-type drugs produced a marked increase of cytotoxicity. However, this approach to RAPTA compounds (Scheme 2b) does not enhance their cytotoxicity towards cancer cell lines, instead it leads to undesired toxicity towards non-cancerous cells. This evidence was explained on the basis of the reduced intracellular uptake due to the functional group, and possibly, easier release of hydrophilic arenes from the Ru-PTA unit, compared to the lipophilic ones. ${ }^{[17]}$ However, using arenes with pyrenyl-substituents ${ }^{[18]}$ or strongly electron withdrawing, fluorinated groups (Scheme 2c) determines a considerable increment of cytotoxicity towards A2780 cell lines, compared to RAPTA C. Given the electron-withdrawing nature of the arene, the $\mathrm{Ru}$-arene bond is expected to be relatively weak, and this feature might contribute to the enhanced cytotoxity. Interestingly, the rate of hydrolysis in these complexes was found to be favourable especially at low $\mathrm{pH}$ values, thus providing a possible method of tumour targeting, con- 
sidering that low $\mathrm{pH}$ values are typical for the tumour environment. [19]

With the idea in mind that the combination of more than one pharmacophore may enhance the anticancer potency of the drug, the RAPTA-benzene frame was also derivatised by an elegant synthetic procedure with chloroambucil, i.e. an organic compound used as an orally administered chemotherapeutic (Scheme 3). ${ }^{[20]}$ This strategy provided compounds with excellent in vitro anticancer activity against cisplatin-resistant cancer cells, superior to those of chlorambucil itself, RAPTA-T or a mixture of both.

A simple RAPTA-C variant (RACAP-C), containing a phosphorus ligand closely resembling PTA, has been recently reported by Peruzzini (Fig. 3); this compound has higher antiproliferative activity than the PTA analogue and displays a reasonable degree of cancer cell selectivity. [21]

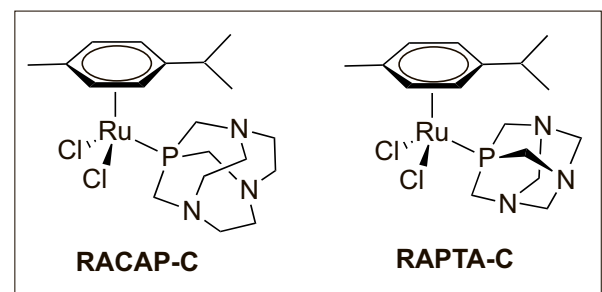

Fig. 3. Comparative view of the structures of RACAP-C and RAPTA-C.

Another possible change of the RAPTA structural motif is the replacement of both chloride ligands with bioactive, mono-anionic $\beta$-diketonate moieties. Pettinari and coworkers reported a series of such compounds. Thus, $\left[\mathrm{Ru}\left(\eta^{6}\right.\right.$-arene $)\left(\kappa^{2} O\right.$-acac*) $(\mathrm{PTA})]^{+}$[arene $=4-\mathrm{C}_{6} \mathrm{H}_{4}(\mathrm{Me})\left({ }^{\mathrm{i}} \mathrm{Pr}\right)$, cymene; $\mathrm{C}_{6} \mathrm{Me}_{6}$, hexamethylbenzene], where the bidentate oxygen donor ( $\mathrm{acac}^{*}$ ) derives from avobenzone, ortho-hydroxydibenzoylmethane or acylpyrazolones, show moderate cytotoxicity with comparable $\mathrm{IC}_{50}$ values between A2780 and A2780R cell lines, but scarce selectivity with respect to non-tumorous cells (Scheme 4A). ${ }^{[22]}$ Of most interest is the use of curcumin as $\beta$-diketonate precursor; in fact, curcumin possesses notable properties, such as antioxidant, antiproliferative, anticancer, and antiangiogenic, and its efficacy in the treatment of a number of diseases has been ascertained. ${ }^{[23]}$ The ruthenium-curcumin compounds (Scheme 4B) showed low $\mathrm{IC}_{50}$ values against tumoral cells, while maintaining an excellent selectivity with respect to non-cancerous human embryonic kidney cells. ${ }^{[24]}$ In these complexes, the PTA ligand is believed to contribute to the pharmacological efficacy in a significant manner, and remarkable proteasome inhibition activity has been ascertained for related neutral species. ${ }^{[25]}$
Berger reported $\left[\mathrm{Ru}\left(\eta^{6}\right.\right.$-arene $)\left(\kappa^{2} O\right.$ $\left.\left.\mathrm{acac}^{\mathrm{F}}\right)(\mathrm{PTA})\right]^{+}$complexes (Scheme 4C), containing fluorinated $\beta$-diketonate ligands $\left(\operatorname{acac}^{\mathrm{F}}\right)$, which showed a variable antiproliferative activity against ovarian and osteosarcoma cancer cells, but were substantially inactive against non-malignant keratinocytes. ${ }^{[26]}$ The presence of the PTA ligand confers to the complexes higher inertness with respect to hydroly- sis, compared to the corresponding neutral compounds containing a chloride in place of PTA. Indeed, stability studies in aqueous solution of $\left[\mathrm{Ru}\left(\eta^{6}\right.\right.$-arene $\left.)\left(\kappa^{2} O-\mathrm{acac}^{\mathrm{F}}\right)\right]$ complexes evidenced the slow, partial release of the bidentate $O, O$-donor, besides the typical, quick chloride elimination.

RAPTA complexes modified with $\beta$-ketoamine ligands are still considerably cytotoxic in vitro, exhibiting significant

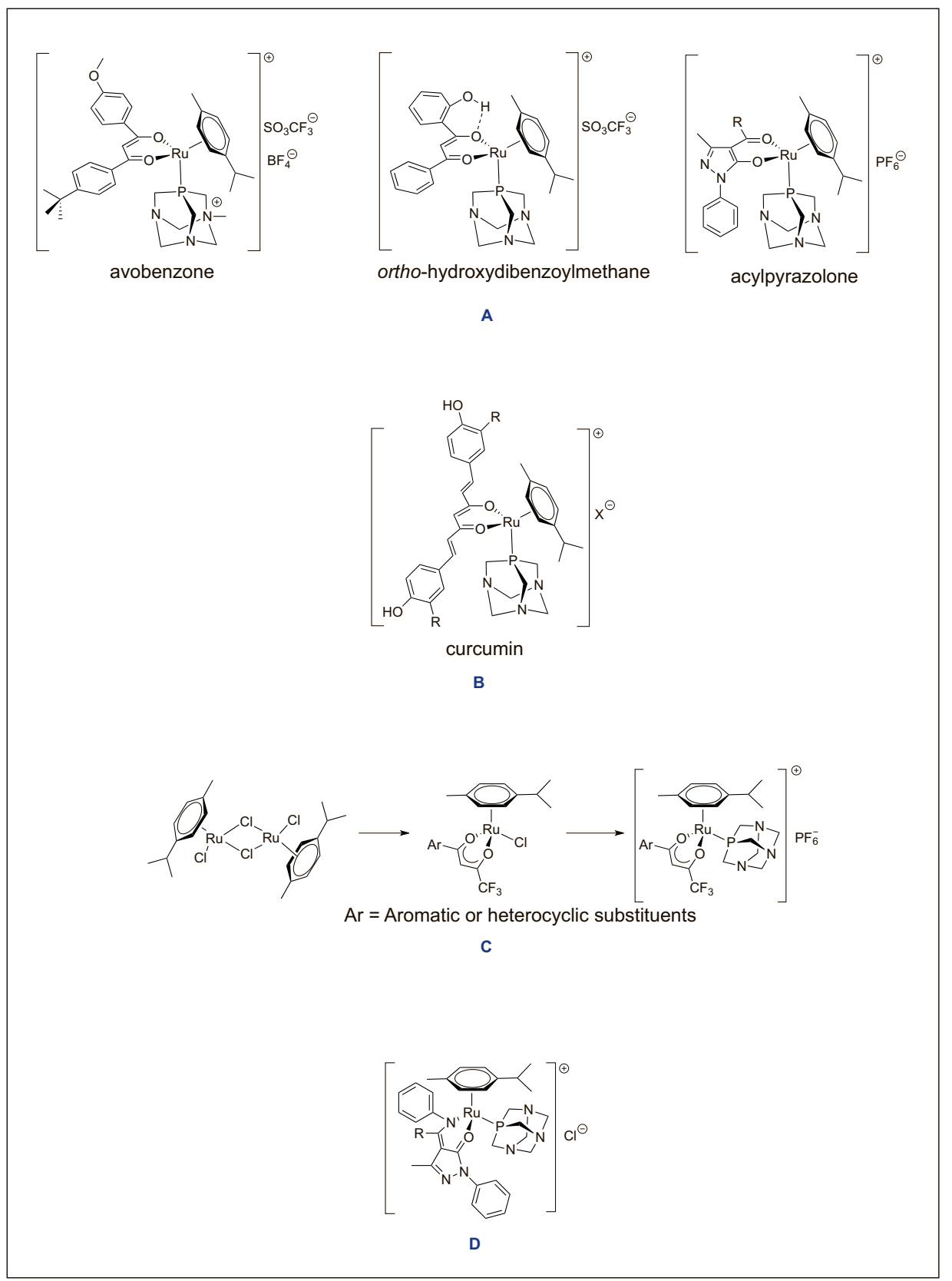

Scheme 4. Examples of RAPTA derivatives with $\beta$-diketonate $(A-C)$ and $\beta$-ketoiminate $(D)$ ligands tested for their anticancer activity.

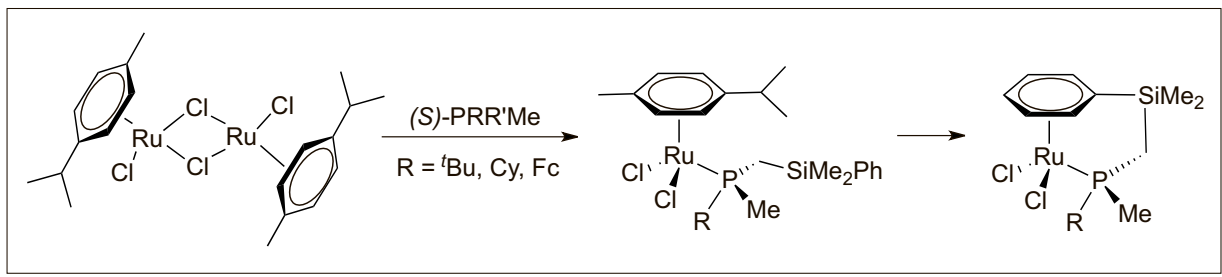

Scheme 5. Ruthenium(II) arene compounds with stereogenic trialkylphosphines. 
cytotoxicity even against cisplatin resistant ovarian A2780 cancer cells (Scheme 4D); the anticancer behaviour of these complexes seems to be finely tuneable by slight structural modifications on the $\beta$-ketoamine fragment.[27]

\section{Ruthenium Complexes with Other Phosphine Ligands}

A variety of complexes obtained by formal replacement of PTA with an alternative P-ligand have been prepared and evaluated as anticancer agents. Some complexes of general formula $\left[\mathrm{Ru}\left(\eta^{6}-p\right.\right.$-cymene $\left.) \mathrm{Cl}_{2}(P)\right]$, containing a stereogenic trialkylphosphine ligand with a silicon side-group $(P)$, were evaluated against human leukaemia cancer cells (HL-60), exhibiting $\mathrm{IC}_{50}$ values in the same order of magnitude as cisplatin. ${ }^{[28]}$ An analogous complex in which one of the P-substituents is tethered to the arene ring through a short spacer, was found to be considerably less cytotoxic (Scheme 5).

Similarly, complexes with aminomethylphosphanes, i.e. [ $\left(\eta^{6}-p\right.$-cymene $)$ $\left.\mathrm{RuCl}_{2}\left(\mathrm{PPh}_{2} \mathrm{R}\right)\right]$, were studied for their cytotoxicity against the A549 (human lung adenocarcinoma) and MCF7 (human breast adenocarcinoma) cell lines, showing activities comparable to that of cispla-
Fig. 4. Ru(II) p-cymene compounds with: a) aminomethylphosphines; b) aminophosphines.
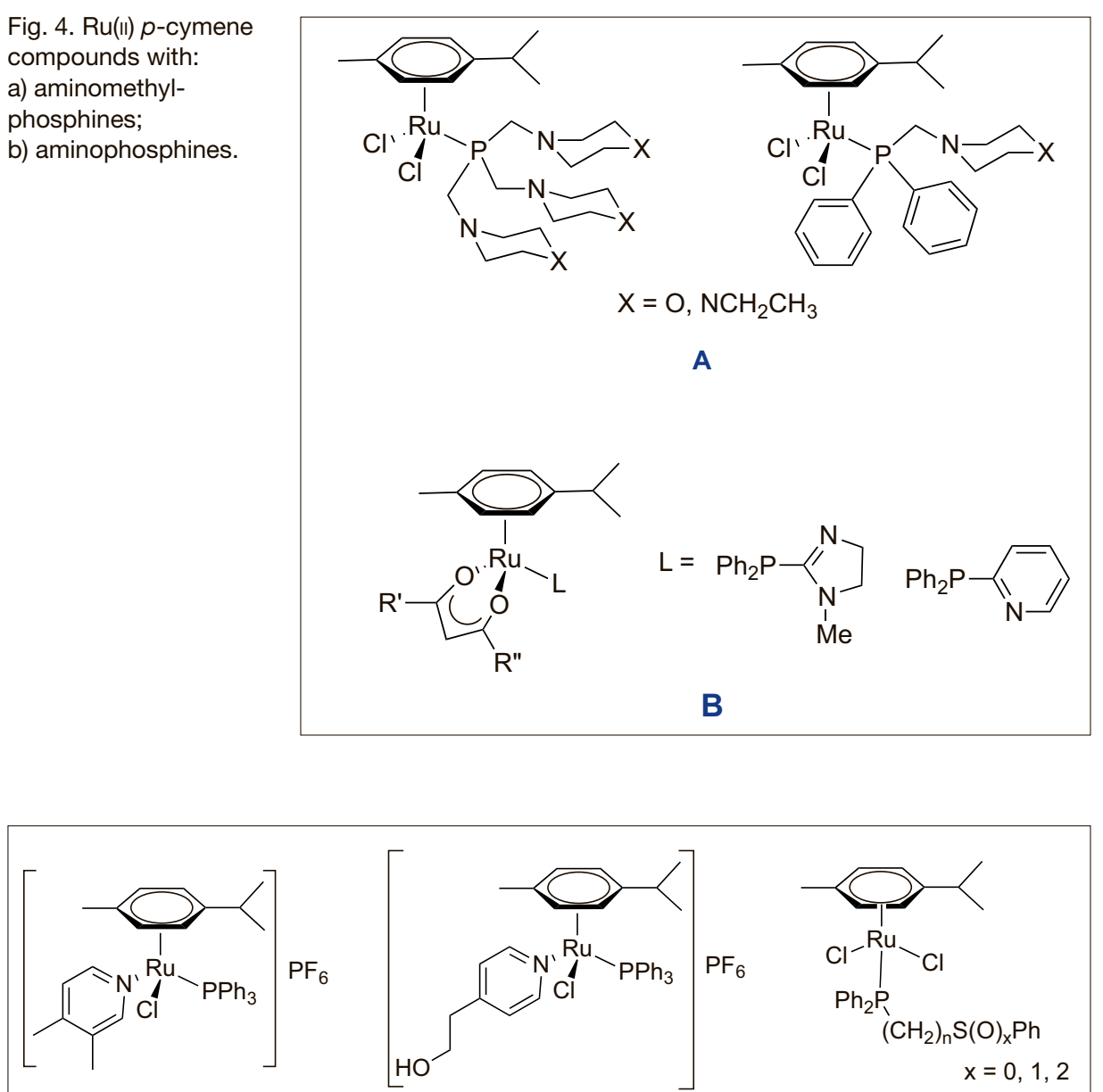

Fig. 5. $\mathrm{Ru}(I) p$-cymene complexes with pyridine ligands or chelating P,S ligands.

Fig. 6. Cationic Ru(II) arene complexes with mono- or bidentate triphenylphosphine ligands.

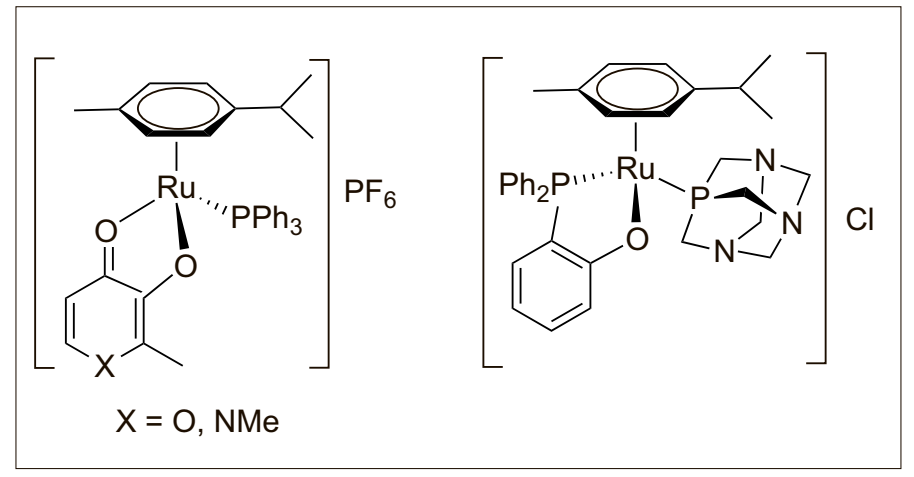

tin (Fig. 4a). All of these complexes are able to interact with transferrin and DNA, which can be viewed as possible drug targets. [29]

Aminophosphines complexes with a $\beta$-diketonate ligand, i.e. $\left[\mathrm{Ru}\left(\eta^{6}-p\right.\right.$-cymene $)$ $(O, O$-acac $\left.)\left(\mathrm{PPh}_{2} \mathrm{R}\right)\right] \quad(\mathrm{R}=2$-pyridine or imidazole), exhibit moderate to good cytotoxic behaviour in vitro against the human cancer cell lines MCF-7 (breast cancer) and CAPAN-1 (pancreatic cancer), see Fig. 4b. ${ }^{[30]}$ By modulating the nature of the $\mathrm{R}$ group, it is possible to tune the activity, the best results being achieved with the pyridine species. These are supposed to quickly release the $\beta$-diketonate moiety in aqueous environment, possibly due to the donor ability of the pyridine group activating the complex.

The introduction of a triphenylphosphine ligand usually enhances the hydrophobicity of the resulting ruthenium arene complex, thus leading to higher levels of cytotoxicity in vitro. However, this can result in decrease of selectivity on the other hand, as has been ascertained by replacing one chloride with triphenylphosphine in RAPTA-C and RAPTA-OH complexes. [31]

Cationic complexes $\left[\mathrm{Ru}\left(\eta^{6}-p\right.\right.$-cymene $)$ (py) $\left.\mathrm{Cl}\left(\mathrm{PPh}_{3}\right)\right]^{+}$, bearing a pyridine (py) ligand (Fig. 5), showed $\mathrm{IC}_{50}$ values against human leukaemia tumour cell line comparable to that obtained with cisplatin. It has been demonstrated that the ruthenium triphenylphosphine complexes are able to bind DNA and distort its secondary and tertiary structure, whereas analogous complexes lacking of $\mathrm{PPh}_{3}$ bind DNA in a covalent manner only. ${ }^{[32]}$ Arene ruthenium complexes with S-functionalized phosphine ligands were revealed to be potently cytotoxic (cell lines 518A2, 8505C, A253, MCF-7, SW480), with higher antiproliferative activity with respect to the parent neutral complexes (Fig. 5). A correlation has been found between the lengths of the methylene spacers and the cytotoxic activity (MCF-7, SW480 cells), i.e. the longer the spacer the higher the in vitro activity. ${ }^{[33]}$

In general, the highest levels of cytotoxity were reached with the sulphide-containing ligands. Hartinger recently found that the incorporation of $\mathrm{PPh}_{3}$ within $\mathrm{Ru}(\mathrm{II})$ arene complexes of 3-hydroxy4(1H)-pyr(id)one ligands (Fig. 6) resulted in a dramatic increase in the antiproliferative activity against human colorectal (HCT116), cervical (SiHa), non-small cell lung (NCI-H460), and colon (SW480) carcinoma cell lines. ${ }^{[34]}$ A similar effect was ascertained for letrozole-ruthenium analogues. ${ }^{[35]}$ Alternatively to the use of $\beta$-diketonate ligands (see above), that of (ortho-hydroxyphenyl)diphenyl phosphine may be taken into consideration: the ionic compound $\left[\mathrm{Ru}\left(\eta^{6}-p\right.\right.$-cymene $)\left\{\kappa^{2} P, O-\mathrm{PPh}_{2}\right.$ $\left.\left.\left(2-\mathrm{C}_{6} \mathrm{H}_{4} \mathrm{O}\right)\right\}(\mathrm{PTA})\right] \mathrm{Cl}$ is weakly cytotoxic 


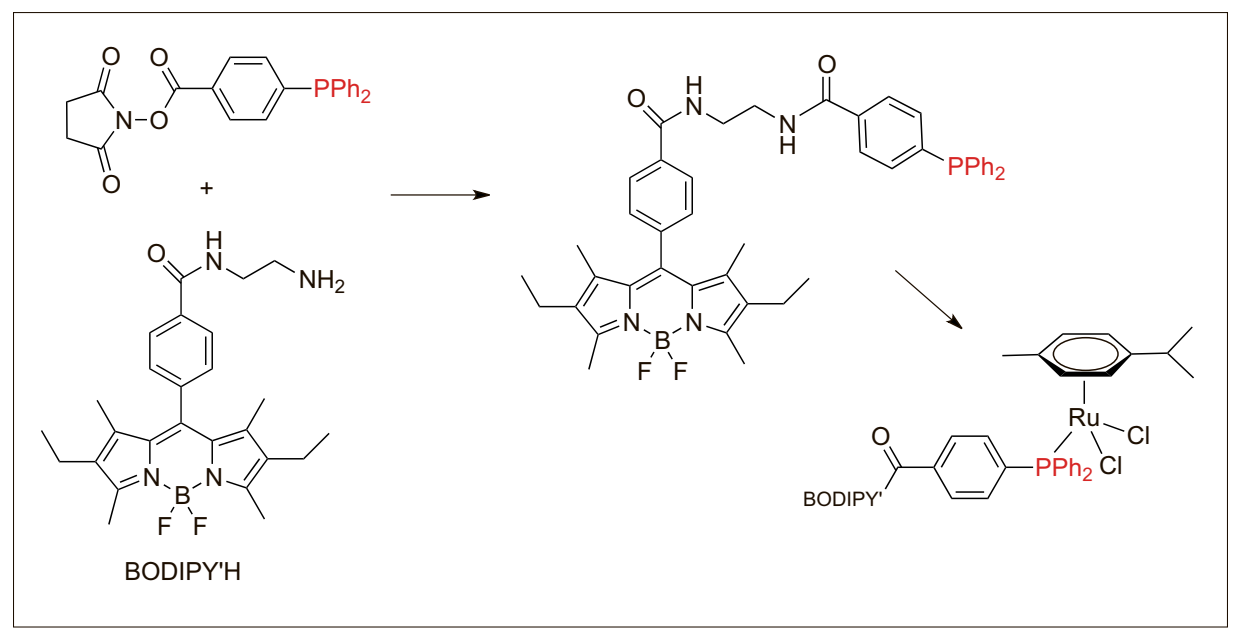

Scheme 6. Functionalization with BODIPY at a triphenylphosphine ligand affording fluorescent complexes.

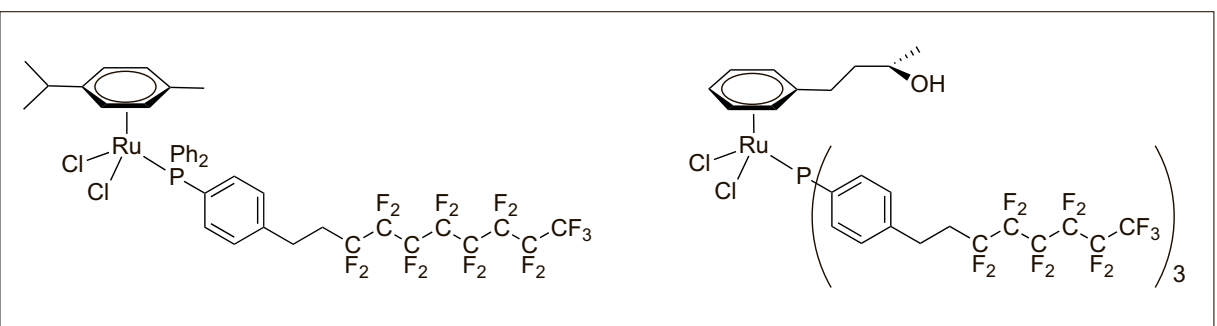

Fig. 7. Examples of incorporation of perfluorinated phosphine ligands in ruthenium arene complexes inducing thermotropic behaviour.

$\left(\mathrm{IC}_{50}=138 \mu \mathrm{M}\right)$ on $\mathrm{A} 2780$ ovarian cancer cells, moreover it is inert in aqueous solution and with respect to possible cellular targets, therefore it is assumed to act through non covalent interactions (Fig. 6). ${ }^{[36]}$

The triphenylphosphine moiety can also be employed as a versatile scaffold for tethering specific functionalities to the ruthenium centre. For instance, derivatization of a triphenylphosphine with BODIPY gave access to highly fluorescent ruthenium arene complexes (Scheme 6). Monitoring the drug uptake in cancer cells in vitro, it has been possible to establish the preferential accumulation of the Ru-species in the cell membranes, without being able to reach the nuclei. ${ }^{[37]}$

An interesting approach to supply selectivity to the ruthenium drug consists in replacing the PTA ligand with a perfluorinated phosphine, i.e. a phosphine bearing fluourous alkyl chains, whose solubility is strictly dependant on the temperature. ${ }^{[38]}$ For instance, the solubility of $\mathrm{P}\left(\mathrm{C}_{2} \mathrm{H}_{4} \mathrm{C}_{8} \mathrm{~F}_{17}\right)_{3}$ in octane increases by 600 times in the temperature range -20 to $80{ }^{\circ} \mathrm{C} .{ }^{[39]}$ As a further modification, the amphiphilic phosphine PTA ligand can be added in place of a chloride ligand (Fig. 7). Up to four-fold increase in water solubility of some of the ruthenium derivatives has been detected at $42{ }^{\circ} \mathrm{C}$, making such compounds suitable candidates for thermal chemotherapy. possible cancer cell selectivity supplied by the carbohydrate moiety (Scheme 7). ${ }^{40]}$ Indeed the resulting complexes showed a certain degree of selectivity against several cancer cell lines compared to the non-tumorigenic cell line. The best performance was achieved by increasing the lipophilicity of the carbohydrate-mimicking group, ${ }^{[41]}$ while the introduction of a bis-carboxylate ligand in place of two halides led to a decrease of the in vitro anticancer activity. ${ }^{[42]}$

The phosphine $\mathrm{PPh}_{2}\left(4-\mathrm{C}_{6} \mathrm{H}_{4} \mathrm{CO}_{2} \mathrm{H}\right)$ is relatively air stable and it has been used to obtain a series of phosphine ligands derivatised with bioactive groups, more precisely ethacrynic acid, ${ }^{[43]}$ indomethacin and diclofenac. ${ }^{[44]}$ The latter two are anti-inflammatory drugs, whereas ethacrynic acid is an inhibitor of GSTs enzymes, these enzymes being involved in cell resistance mechanisms. The resulting $\left[\mathrm{Ru}\left(\eta^{6}\right.\right.$ - $p$-cymene $\left.) \mathrm{Cl}_{2}(P)\right]$ complexes display moderate to good activity towards A2780 and A2780cisR cancer cells, with some difference in the activity compared to the respective phosphine ligands (Fig. 8). However, none of these complexes showed selectivity between the cancer cells and the non tumorigenic cell line.

The phosphine $\mathrm{PPh}_{2}\left(4-\mathrm{C}_{6} \mathrm{H}_{4} \mathrm{OH}\right)$ and its ester derivatives are significantly less air tolerant compared to $\mathrm{PPh}_{2}(4-$ $\mathrm{C}_{6} \mathrm{H}_{4} \mathrm{CO}_{2} \mathrm{H}$ ). Notwithstanding, the former can be employed as a convenient linker of bioactive carboxylic acids to the ruthenium moiety, according to a general method. ${ }^{[45]}$ Hence, the complex $\left[\left(\eta^{6}-p\right.\right.$-cymene $)$ $\left.\mathrm{RuCl}_{2}\left(\kappa P-\mathrm{PPh}_{2}\left(4-\mathrm{C}_{6} \mathrm{H}_{4} \mathrm{OH}\right)\right)\right]^{[46]}$ has been coupled with a series of bioactive carboxylic acids via direct esterification of the hydroxyl group belonging to the coordinated phosphine ligand (Fig. 9). This procedure negates the need for protecting strategies, since the chloride ligands are not affected by the functionalization reactions. The resulting complexes, in general, display $\mathrm{IC}_{50}$ values in the range 9 to $50 \mathrm{mM}$ towards the ovarian cancer cells A2780 and A2780cisR, but no selectivity compared

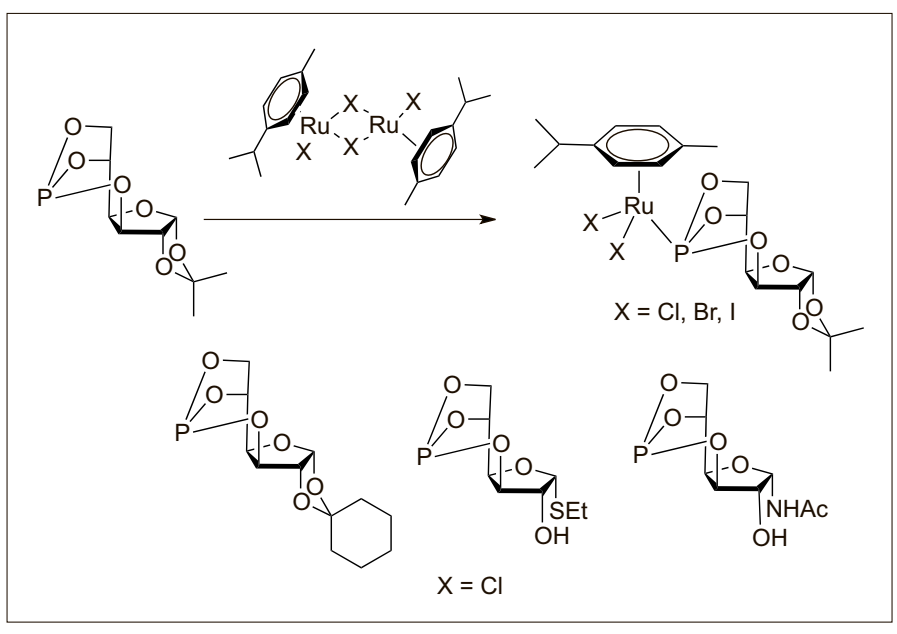

Scheme 7. Introduction of a carbohydrate moiety in a $\mathrm{Ru}($ II) arene compound via 3,5,6-bicyclophosphite coordination. 


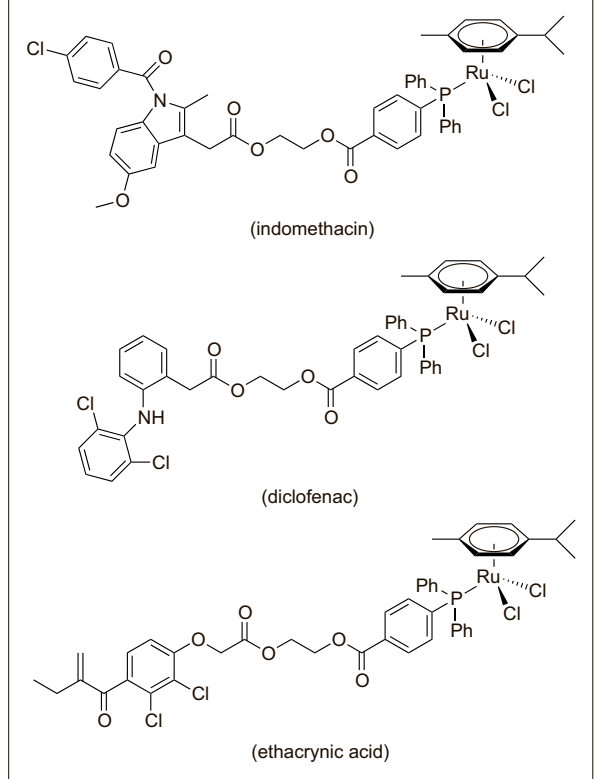

Fig. 8. Triphenylphosphine complexes functionalized with bioactive groups.

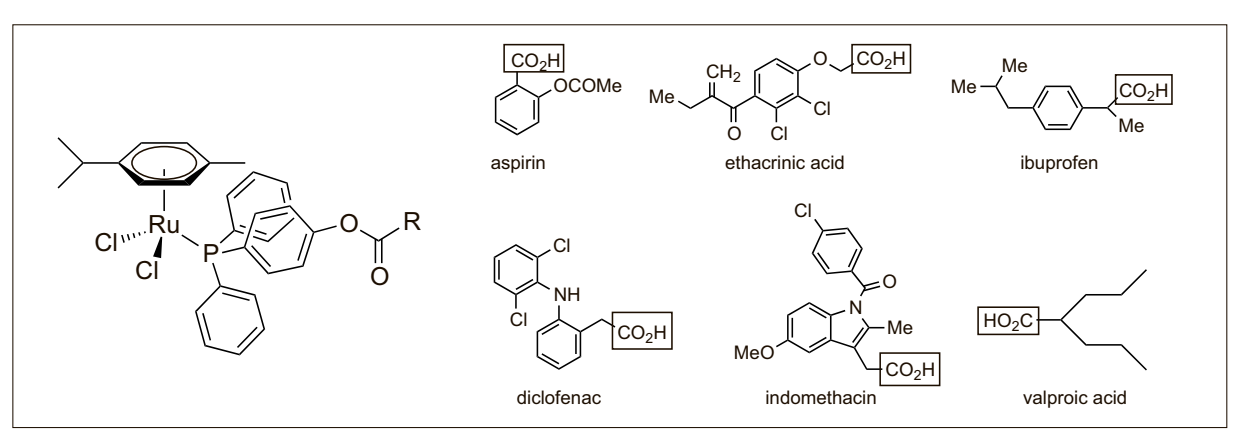

Fig. 9. Functionalization of $p$-cymene complexes with bioactive carboxylic acids $\left(\mathrm{RCO}_{2} \mathrm{H}\right)$, obtained by direct esterification of coordinated (4-hydroxyphenyl)diphenylphosphine.
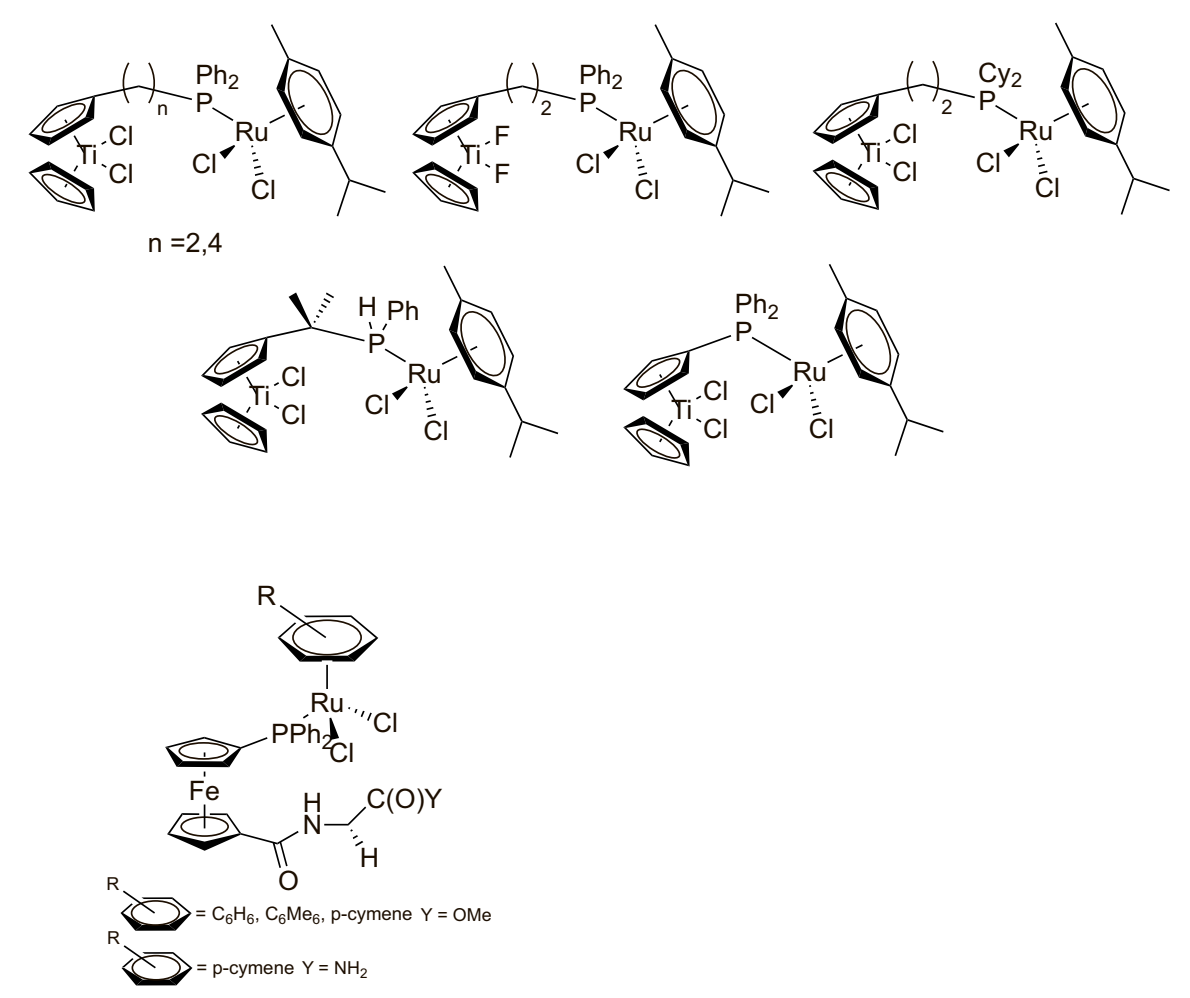

Fig. 10. Ferrocene and titanocene dichloride complexes conjugated to a $\left[\mathrm{Ru}\left(\eta^{6}\right.\right.$-arene $\left.) \mathrm{Cl}_{2}\right]$ frame via a phosphine ligand. to non-tumorigenic cells. The cytotoxicity data clearly evidence a synergic contribution of the Ru-arene frame and the bioactive group to the antiproliferative potential of the overall complex.

\section{Heterobimetallic Complexes}

Phosphine units have been used to connect transition metal frames with potential anticancer activity to the Ru(II) arene skeleton, leading to heteronuclear compounds. This approach has allowed the combination with the titanocene dichloride moiety, aimed to conjugate the anticancer properties of the respective titanium and ruthenium species (Fig. 10). ${ }^{[47]}$ Interestingly, the obtained hetero-dinuclear compounds were found to be considerably more active against the A2780 cancer cell line than their parent mononuclear $\mathrm{Ti}$ and $\mathrm{Ru}$ precursors,

and even more cytotoxic than cisplatin in the corresponding resistant cell line. [48]

The $\mathrm{RuCl}_{2}$ (arene) fragment has also been connected to a ferrocenyl diphenyl phosphine, the resulting ruthenium-ferrocene conjugate showing moderate to good in vitro anticancer activity (A2780 and A2780cisR cell lines). ${ }^{[49]}$

\section{Conclusions}

Ruthenium(II) complexes of the RAPTA series, $\left[\mathrm{Ru}\left(\eta^{6}\right.\right.$-arene $) \mathrm{Cl}_{2}$ (PTA) $]$, are promising anticancer agents, exhibiting low cytotoxicity in vitro but notable antimetastatic and antiangiogenic activity in vivo. A variety of structural modifications have been performed in order to modulate the activity of the complexes, including functionalization of the arene ring, introduction of bidentate donors in the place of the chloride ligands, diversification of the phosphorus ligand, introduction of bioactive groups and combination with heterometallic fragments. This plethora of structural possibilities provide several opportunities in terms of solubility, biological behaviour, antiproliferative activity in vivo and, possibly, in vivo performance of the potential drugs. A development and extensive biological investigation ${ }^{[50]}$ of these systems could lead to fundamental steps in the direction of fighting cancer.

\section{Acknowledgements}

We wish to acknowledge all the people collaborating with us in this research field, and the University of Pisa for financial support (PRA 2017: "Composti di metalli di transizione come possibili agenti antitumorali”).

Received: July 262017

[1] a) C. G. Hartinger, N. Metzler-Nolte, P. J. Dyson, Organometallics 2012, 31, 5677; b) G. Gasser, I. Ott, N. Metzler-Nolte, J. Med. Chem. 2011, 54, 3; c) S. H. van Rijt, P. J. Sadler, Drug Disc. Today 2009, 14, 1089.

[2] a) E. Alessio, Eur. J. Inorg. Chem. 2017, 1549; b) A. Bergamo, G. Sava, Chem. Soc. Rev. 2015 , 44, 8818; c) R. Trondl, P. Heffeter, C. R. Kowol, M. A. Jakupec, W. Berger, B. K. Keppler, Chem. Sci. 2014, 5, 2925; d) E. Alessio, G. Mestroni, A. Bergamo, G. Sava, Curr. Topics Med. Chem. 2004, 4, 1525.

[3] I. Bratsos, T. Gianferrara, E. Alessio, C. G. Hartinger, M. A. Jakupec, B. K. Keppler, in 'Bioinorganic Medicinal Chemistry', Ed. E. Alessio, Wiley-VCH, Weinheim, 2011, p. 151.

[4] a) A. K. Singh, D. S. Pandey, Q. Xu, P. Braunstein, Coord. Chem. Rev. 2014, 270, 31; b) M. V. Babak, D. Plazuk, S. M. Meier, H. J. Arabshahi, J. Reynisson, B. Rychlik, A. Błauz, K. Szulc, M. Hanif, S. Strobl, A. Roller, B. K. Keppler, C. G. Hartinger, Chem. Eur. J. 2015, 21,5110 ; c) A. A. Nazarov, C. G. Hartinger, P. J. Dyson, J. Organomet. Chem. 2014, 751, 251; d) A. L. Noffke, A. Habtemariam, A. M. Pizarro, 
P. J. Sadler, Chem. Commun. 2012, 48, 5219, e) M. Melchart, P. J. Sadler, Ed. G. Jaouen, Bioorganometallics 2006, 39.

[5] a) B. S. Murray, M. V. Babak, C. G. Hartinger, P. J. Dyson, Coord. Chem. Rev. 2016, 306, 86; b) A. Weiss, R. H. Berndsen, M. Dubois, C. Müller, R. Schibli, A. W. Griffioen, P. J. Dyson, P. Nowak-Sliwinska, Chem. Sci. 2014, 5, 4742 c) C. Scolaro, A. Bergamo, L. Brescacin, R Delfino, M. Cocchietto, G. Laurenczy, T. J. Geldbach, G. Sava, P. J. Dyson, J. Med. Chem. 2005, 48, 4161.

[6] a) S. M. Guichard, R. Else, E. Reid, B. Zeitlin, R. Aird, M. Muir, M. Dodds, H. Fiebig, P. J. Sadler, Biochem. Pharmacol. 2006, 71, 408; b) A. Habtemariam, M. Melchart, R. Fernández, S. Parsons, I. D. H. Oswald, A. Parkin, F. P A. Fabbiani, J. E. Davidson, A. Dawson, R. E. Aird, D. I. Jodrell, P. J. Sadler, J. Med. Chem. 2006, 49, 6858 .

[7] Z. Adhireksan, G. E. Davey, P. Campomanes, M. Groessl, C. M. Clavel, H. Yu, A. A. Nazarov, C. Hui Fang Yeo, W. H. Ang, P. Dröge, U. Rothlisberger, P. J. Dyson, C. A. Davey, Nature Commun. 2014, 5, 3462.

[8] M. A. Bennett, A. K. Smith, J. Chem. Soc. Dalton Trans. 1974, 233.

[9] C. S. Allardyce, P. J. Dyson, D. J. Ellis, S. L. Heath, Chem. Commun. 2001, 1396.

[10] A. Weiss, R. H. Berndsen, M. Dubois, C. Muller, R. Schibli, A. W. Griffioen, P. J. Dyson, P. Nowak-Sliwinska, Chem. Sci. 2014, 5, 4742.

[11] a) S. Chatterjee, S. Kundu, A. Bhattacharyya, C. G. Hartinger, P. J. Dyson, J. Biol. Inorg. Chem. 2008, 13, 1149. b) C. Scolaro, A. Bergamo, L. Brescacin, R. Delfino, M. Cocchietto, G Laurenczy, T. J. Geldbach, G. Sava, P. J. Dyson, J. Med. Chem. 2005, 48, 4161.

[12] a) M. V. Babak, S. M. Meier, K. V. M. Huber, J. Reynisson, A. A. Legin, M. A. Jakupec, A Roller, A. Stukalov, M. Gridling, K. L. Bennett, J. Colinge, W. Berger, P. J. Dyson, G. SupertiFurga, B. K. Keppler, C. G. Hartinger, Chem Sci. 2015, 6, 2449; b) B. Wu, M. S. Ong, M Groessl, Z. Adhireksan, C. G. Hartinger, P. J. Dyson, C. A. Davey, Chem. Eur. J. 2011, 17 3562; A. Casini, G. Mastrobuoni, W. H. Ang, C. Gabbiani, G. Pieraccini, G. Moneti, P. J. Dyson, L. Messori, ChemMedChem 2007, 2, 631.

[13] C. Scolaro, C. G. Hartinger, C. S. Allardyce, B. K. Keppler, P. J. Dyson, J. Inorg. Biochem. 2008, 102, 1743 .

[14] A. Dorcier, W. H. Ang, S. Bolano, L. Gonsalvi, L. Juillerat-Jeannerat, G. Laurenczy, M. Peruzzini, A. D. Phillips, F. Zanobini, P. J Dyson, Organometallics 2006, 25, 4090.

[15] W. H. Ang, E. Daldini, C. Scolaro, R. Scopelliti, L. Juillerat-Jeannerat, P. J. Dyson, Inorg. Chem. 2006, 45, 9006

[16] B. S. Murray, L. Menin, R. Scopelliti, P. J. Dyson, Chem. Sci. 2014, 5, 2536.

[17] C. Scolaro, T. J. Geldbach, S. Rochat, A. Dorcier, C. Gossens, A. Bergamo, M. Cocchietto, I. Tavernelli, G. Sava, U. Rothlisberger, P. J Dyson, Organometallics 2006, 25, 756.

[18] M. A. Furrer, F. Schmitt, M. Wiederkehr, L. Juillerat-Jeanneret, B. Therrien, Dalton Trans. 2012, 41, 7201 .
[19] a) A. E. Egger, C. G. Hartinger, A. K. Renfrew, P. J. Dyson, J. Biol. Inorg. Chem. 2010, 15, 919; b) A. K. Renfrew, A. D. Phillips, E. Tapavicza, R. Scopelliti, U. Rothlisberger, P. J. Dyson, Organometallics 2009, 28, 5061.

[20] A. A. Nazarov, S. M. Meier, O. Zava, Y. N. Nosova, E. R. Milaeva, C. G. Hartinger, P. J. Dyson, Dalton Trans. 2015, 44, 3614.

[21] A. Guerriero, W. Oberhauser, T. Riedel, M. Peruzzini, P. J. Dyson, L. Gonsalvi, Inorg. Chem. 2017, 56, 5514.

[22] a) R. Pettinari, F. Marchetti, A. Petrini, C. Pettinari, G. Lupidi, P. Smoleński, R. Scopelliti, T. Riedel, P. J. Dyson, Organometallics 2016, 35 , 3734; b) R. Pettinari, A. Petrini, F. Marchetti, C. Pettinari, T. Riedel, B. Therrien, P. J. Dyson, Eur. J. Inorg. Chem. 2017, 1800; c) J. Palmucci, F. Marchetti, R. Pettinari, C. Pettinari, R. Scopelliti, T. Riedel, B. Therrien, A. Galindo, P. J. Dyson, Inorg. Chem. 2016, 55, 11770.

[23] a) K. M. Nelson, J. L. Dahlin, J. Bisson, J. Graham, G. F. Pauli, M. A. Walters, J. Med. Chem. 2017, 60, 1620; b) M. Pröhl, U. S. Schubert, W. Weigand, M. Gottschaldt, Coord. Chem. Rev. 2016, 307, 32; c) S. Banerjee, A. R. Chakravarty, Acc. Chem. Res. 2015, 48, 2075.

[24] a) R. Pettinari, F. Marchetti, F. Condello, C. Pettinari, G. Lupidi, R. Scopelliti, S. Mukhopadhyay, T. Riedel, P. J. Dyson, Organometallics 2014, 33, 3709; b) F. Caruso, M. Rossi, A. Benson, C. Opazo, D. Freedman, E. Monti, M. B. Gariboldi, J. Shaulky, F Marchetti, R. Pettinari, C. Pettinari, J. Med. Chem. 2012, 55, 1072.

[25] L. Bonfili, R. Pettinari, M. Cuccioloni, V. Cecarini, M. Mozzicafreddo, M. Angeletti, G. Lupidi, F. Marchetti, C. Pettinari, A. M. Eleuteri, ChemMedChem 2012, 7, 2010.

[26] S. Seršen, J. Kljun, K. Kryeziu, R. Panchuk, B. Alte, W. Körner, P. Heffeter, W. Berger, I. Turel, J. Med. Chem. 2015, 58, 3984.

[27] R. Pettinari, C. Pettinari, F. Marchetti, C. M. Clavel, R. Scopelliti, P. J. Dyson, Organometallics 2013, 32, 309.

[28] R. Aznar, A. Grabulosa, A. Mannu, G. Muller, D. Sainz, V. Moreno, M. Font-Bardia, T. Calvet, J. Lorenzo, Organometallics 2013, 32, 2344.

[29] M. Płotek, R. Starosta, U. K. Komarnicka, A. Skórska-Stania, P. Kołoczek, A. Kyzioł, J. Inorg. Biochem. 2017, 170, 178.

[30] C. Aliende, M. Pérez-Manrique, F. A. Jalón, B. R. Manzano, A. M. Rodríguez, J. V. Cuevas,

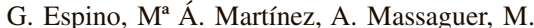
González-Bártulos, R. de Llorens, V. Moreno, J. Inorg. Biochem. 2012, 117, 171

[31] C. Scolaro, A. B. Chaplin, C. G. Hartinger, A. Bergamo, M. Cocchietto, B. K. Keppler, G. Sava, P. J. Dyson, Dalton Trans. 2007, 5065

[32] R. Sáez, J. Lorenzo, M. J. Prieto, M. FontBardia, T. Calvet, N. Omeñaca, M. Vilaseca, V. Moreno, J. Inorg. Biochem. 2014, 136, 1.

[33] G. Ludwig, G. N. Kaluderović, T. Rüffer, M. Bette, M. Korb, M. Block, R. Paschke, H. Lang, D. Steinborn, Dalton Trans. 2013, 42, 3771.

[34] S. Parveen, M. Hanif, S. Movassaghi, M. P. Sullivan, M. Kubanik, M. A. Shaheen, T. Söhnel, S. M. F. Jamieson, C. G. Hartinger, Eur. J. Inorg. Chem. 2017, 1721.
[35] A. Castonguay, C. Doucet, M. Juhas, D Maysinger, J. Med. Chem. 2012, 55, 8799.

[36] A. K. Renfrew, A. E. Egger, R. Scopelliti, C. G. Hartinger, P. J. Dyson, C. R. Chimie 2010, 13, 1144.

[37] S. Tasan, O. Zava, B. Bertrand, C. Bernhard, C. Goze, M. Picquet, P. Le Gendre, P. Harvey, F. Denat, A. Casini, E. Bodio, Dalton Trans. 2013, 42, 6102 .

[38] A. K. Renfrew, R. Scopelliti, P. J. Dyson, Inorg. Chem. 2010, 49, 2239.

[39] a) T. Soos, B. L. Bennett, D. Rutherford, L. P. Barthel-Rosa, J. A. Gladysz, Organometallics 2001, 20, 3079; b) M. Wende, J. A. Gladysz, J. Am. Chem. Soc. 2003, 19, 5861.

[40] M. Patra, T. C. Johnstone, K. Suntharalingam, S. J. Lippard, Angew. Chem. Int. Ed. 2016, 55, 2550.

[41] I. Berger, M. Hanif, A. A. Nazarov, C. G Hartinger, R. O. John, M. L. Kuznetsov, M. Groessl, F. Schmitt, O. Zava, F. Biba, V. B. Arion, M. Galanski, M. A. Jakupec, L. JuilleratJeanneret, P. J. Dyson, B. K. Keppler, Chem. Eur. J. 2008, 14, 9046.

[42] M. Hanif, S. M. Meier, W. Kandioller, A. Bytzek, M. Hejl, C. G. Hartinger, A. A. Nazarov, V. B. Arion, M. A. Jakupec, P. J. Dyson, B. K. Keppler, J. Inorg. Biochem. 2011, 105, 224.

[43] a) G. Agonigi, T. Riedel, S. Zacchini, E. Pǎunescu, G. Pampaloni, N. Bartalucci, P. J. Dyson, F. Marchetti, Inorg. Chem. 2015, 54, 6504; b) G. Agonigi, T. Riedel, M. P. Gay, L. Biancalana, E. Oñate, P. J. Dyson, G. Pampaloni, E. Păunescu, M. A. Esteruelas, F. Marchetti, Organometallics 2016, 35, 1046.

[44] E. P?unescu, S. McArthur, M. Soudani, R. Scopelliti, P. J. Dyson, Inorg. Chem. 2016, 55, 1788 .

[45] L. Biancalana, L. Batchelor, A. De Palo, S. Zacchini, G. Pampaloni, P. J. Dyson, F. Marchetti, Dalton Trans. 2017, Doi:10.1039/ C7DT02062G

[46] I. Angurell, C.-O. Turrin, R. Laurent, V. Maraval, P. Servin, O. Rossell, M. Seco, A.-M. Caminade, J.-P. Majoral, J. Organomet. Chem. 2007, 692, 1928

[47] E. Y. Tshuva, J. A. Ashenhurst, Eur. J. Inorg. Chem. 2009, 2203.

[48] F. Pelletier, V. Comte, A. Massard, M. Wenzel, S. Toulot, P. Richard, M. Picquet, P. Le Gendre, O. Zava, F. Edafe, A. Casini, P. J. Dyson, J. Med. Chem. 2010, 53, 6923.

[49] J. Tauchman, G. Süss-Fink, P. Stepnicka, O. Zava, P. J. Dyson, J. Organomet. Chem. 2013, 723, 233.

[50] After being considered as a 'non-cytotoxic' antimetastatic agent, NAMI-A has been recently found to exert potent and selective cytotoxic effects in a few leukaemia cell lines: S. Pillozzi, L. Gasparoli, M. Stefanini, M. Ristori, M. D’Amico, E. Alessio, F. Scaletti, A. Becchetti, A. Arcangeli, L. Messori, Dalton Trans. 2014, 43,12150 